\title{
BOARDS AS RESOURCE PROVIDERS AND MONI- TORS FOR RESEARCH AND DEVELOPMENT
}

\author{
Xuanli Xie \\ Peking University • Beijing, China \\ Hugh O'Neill
}

University of North Carolina -- Chapel Hill • Chapel Hill, North Carolina

\section{ABSTRACT}

Innovation is essential for every organization. Yet the relationship between boards and innovation remains unclear. We argue that boards not only monitor, but also provide resources, and innovations require both proper levels of resources (skills) from the board, and appropriate forms of control. In this study, we integrate resource-dependence and agency perspectives to examine how a board's knowledge and skills (board diversity) and a board's preference for behavior based controls (board composition) influence the board's ability to provide resources and design controls, which in turn affect the level of research and development intensity in the firm. Hypotheses are tested using a panel data set of firms in research intensive industries.

\section{INTRODUCTION}

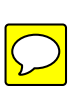

"Every organization needs one core competence, innovation" (Drucker, 1995)

Certainly, most top managers would agree that innovation is essential for the survival of business, especially in these times of technological and global turbulence. Despite this recognition, though, few firms are able to sustain innovation. Each decade seems to bring renewed recognition that inertia drives out innovation in many established firms (Christensen, 1997; Cooper and Schendel, 1976; Miller, 1990). Not surprisingly, CEOs and their top management bear some blame for the problem. Under the pressure of meeting quarterly forecasts, CEOs claim to have little time to formulate and implement long-range growth initiatives.

While there may be a natural excess of managerial myopia within the executive team, we suggest here that part of the cause for near-sighted management may lie with the board of directors. Research has shown that boards can influence major corporate decisions such as strategic changes (Goodstein and Boeker, 1991; Golden and Zajac, 2001), diversification (Amihud and Lev, 1981; Lane, Cannella and Lubatkin, 1998), shifts in R\&D intensity (Baysinger and Hoskisson, 1989; Hill and Snell, 
1988), restructuring (Goodstein, Gautam, and Boeker, 1994; Johnson, Hoskisson, and Hitt, 1993), and corporate entrepreneurship (Zahra, 1996, 2000). Clearly, boards can influence some major change episodes. Yet to date, research has not provided consistent explanations on how boards affect varied aspects of firm innovativeness. For example, Goodstein, Gautam, and Boeker (1994) found that board diversity may hinder the board's ability to initiate strategic change, despite scholars' arguments on how board diversity promotes a wider range of solutions and decision criteria for strategic decisions and encourages strategic change (Eisenhardt \& Bourgeois, 1988; Kosnik, 1990). Another example of inconsistency occurs in investigations of the relationship between outside directors and innovation. Arguments based on agency theory suggest that independent outsiders better align the strategic orientation to stockholders' interest, encouraging more risk-taking and increases in R\&D spending (Kosnik, 1990). However, a number of studies found that the outside director ratio was negatively related to R\&D investment (Baysinger, Kosnik \& Turk, 1991; Hill and Snell, 1988), suggesting that insiders better safeguard innovation. We believe that the inconsistencies in our understanding of the relationship between boards and innovation can be traced to three causes.

First, the board's role is not one dimensional. Boards of directors play multiple roles, which include monitoring management and providing resources (Zahra \& Pearce, 1989; Adams, Hermalin \& Weisbach, 2010). These two roles sometimes are complementary, but at other times may be conflicting. Past research tended to look at each role using differing theoretical lenses. Agency theory has mainly focused on the control role, while resource-dependence theory usually considers the resource role. However, controls and resources are each related to firm innovation. A study combining these two diverse perspectives will provide a clearer picture of how boards influence firm innovation.

Secondly, most investigations focus on the composition of boards. Like all decision making groups, the board's effectiveness depends on its knowledge and skills as well as the way in which the knowledge and skills are used (Forbes \& Milliken, 1999). While board diversity increases the "stock" of board knowledge and skills, the board's orientation towards controls and incentives determines how they transfer their knowledge into final task results. The board's intellectual capital (that is, knowledge and skills) and the board's form of control are two distinctive constructs, and each play a key role in influencing firm activity (Hillman \& Dalziel, 2003). Unfortunately, most research in the past studied these constructs separately. Agency based perspectives over-emphasize controls and incentives at the expense of knowledge, while resource dependency perspectives do the reverse. There is a need 
to integrate these two perspectives as board capital and board approaches to control jointly determine board results.

Finally, the construct of innovation has not been well specified in past studies. Innovation is composed of at least two distinct steps. Innovation requires both search and launch (Burgelman \& Sayles, 1986). Boards affect each step by providing resources and designing controls. Past research on R\&D intensity (Baysinger et. al, 1991; Hill \& Snell, 1999) fails to fully probe the controls and incentives necessary to prompt the risky behavior that research efforts demand (Hoskisson, Hitt, Johnson \& Crossman, 2002).

To provide some insights on these issues, this study will explore the relationship between boards of directors and firm R\&D intensity. Specifically, we examine how the boards' knowledge and skills (measured by board diversity) and the boards' approach to control (measured by board composition) influence the level of research intensity in the firm. Our study integrates agency and resource dependence perspectives.

In the following section, we briefly discuss the two components of innovation (search and risk-taking), two roles of boards (providing resources and controlling), and how the components of innovation and the board roles are linked together. Based on these concepts, we then generate our hypotheses relating variables that link board knowledge and the board's choice of controls with innovation. After presenting our hypotheses, we describe our data and analyses. In the end, we discuss the results and conclusions of this study.

\section{LITERATURE REVIEW}

\section{Search and Risk-Taking In Innovation}

Past research generally treats innovation as a single construct, measured as an input variable such as R\&D intensity, or output variables like new product introductions, the number of patents, etc. However, a more holistic approach to innovation suggests that innovative success requires attention to two stages: the development of ideas and the launching of innovative products (Burgelman \& Sayles, 1986). In the development stage, firms acquire or build their knowledge base for innovation, through a form of organizational search (Cyert \& March, 1963). In the launching stage, firms overcome organizational inertia and take risks. Risk is the "variation in the distribution of outcomes, their likelihoods, and their subjective values"(March and Shapira, 1987). In innovations, taking risk means committing resources toward 
activities with a likelihood of loss (Gomez-Mejia et al, 2007). Each component, search and risk-taking, is necessary for two reasons. First, organizational search can result in either innovative or imitative solutions, thus search itself cannot provide a sufficient condition for innovation. Second, search can only provide a pool of potential solutions, and realization of that potential depends on the risk-taking in the final stages of decision-making. As a result, the rate of innovation is affected by both the search process and the managerial willingness to take risk (Greve, 2003).

We believe it is important to consider these two components of innovation as conceptually different because each component builds on a separate dimension of the board's role in governance. Organizational search is related to organizational learning, which is influenced by the board's resource provision role, while the will to take risks is affected by the board's control role. We will further explain these two roles in the following section.

\section{The Two Roles of The Directors}

\section{The Resource Role}

The resource dependency perspective argues that directors provide access to essential resources through linkages to the external environment (Pfeffer \& Salancik, 1978; Hillman, Withers \& Collins, 2009). Boards are a mechanism for managing and reducing transaction costs associated with external contingencies. Boards are also boundary spanners that provide timely information to executives. Recent research demonstrates that directors bring their knowledge and experience to the board room and affect a variety of firm consequences (Kor \& Misangyi, 2008; Kroll, Walters \& Le, 2007; Jones, Makri \& Gomez-Mejia, 2008). Finally, board members' prestige in their professions and communities can help firms extract resources for successful company operations. In sum, this perspective suggests that directors influence innovation by providing critical resources for the firm in its search for ideas and external support.

R\&D is one form of organization search (Greve, 2003) and it is an important source of internal knowledge (Cardinal \& Hatfield, 2000) and a contributor to the capacity to absorb external knowledge (Cohen \& Levinthal, 1990). While it is a long-established practice that $R \& D$ expenditure is used as a proxy of innovativeness of the firm, R\&D intensity only represents an input to innovation, but cannot measure the direction and amount of risk-taking in innovation. Boards can provide two types of resources to facilitate organizational search through R\&D. First, board 
members bring specific knowledge. Directors provide advice and counsel to R\&D projects. Second, board members span boundaries and link the firm to a broader network. Board members bring external research opportunities to the firm through these linkages. As the resources provide by board increases $R \& D$ intensity increases.

\section{The Control Role}

The directors' control role is to ensure corporate growth and protect shareholder's interest by evaluating company and CEO performance (Zahra \& Pearce, 1989). Agency theory argues that as firms grow large and management and ownership become specialized, conflicts of interest arise (Jensen and Meckling, 1976). One conflict emerges due to different risk preferences. Shareholders prefer high average return on each stock they hold, even at the cost of higher risk, because their overall risk can be reduced by holding diversified portfolios of stocks (Copeland and Weston, 1979). However, management may not want to bear the extra risk because risky projects can trigger poor outcomes which will lead to career failure. Boards of directors align the conflicting interests of owners and management through their choice of control tools and systems (Oviatt, 1988; Walsh and Seward, 1990). One form of control is an incentive contract. The use of incentives based on specific behavior, as opposed to incentives based on outcomes, shifts the potential cost of risk-induced shortfalls in performance to the principal rather than the agent (Eisenhardt, 1985). So boards can use behavior-based control to encourage managerial risk-taking in innovation. The board's composition affects its preference for incentive schemes which, in turn, determines the form of contract used to reward the CEO. In the following section, we develop arguments on how specific board attributes affect their resource and control roles, which in turn impact innovation search and risk-taking.

\section{HYPOTHESES}

Our hypotheses investigate the effect of two aspects of board characteristics on firm innovation. First, we are interested in how board diversity affects organizational search and risk-taking. We argue that board diversity has mixed effects on the board's ability to provide resources and design controls. Second, we are interested on how board composition changes the propensity for the board to engage in providing resources or designing effective controls. 


\section{Board Diversity and Firm Innovation}

Here board diversity refers to the diversity of the board along functional backgrounds. Functional background reflects an individual's core skill set, which is gained through education and job roles and is not very changeable (Tuggle, Schnatterly, \& Johnson, 2010). Functional background schemas shape and frame how managers view and approach issues (Hambrick \& Mason, 1984). Board diversity in background experience influences how the board provides resources, and how the board chooses incentives to monitor and control management.

Board diversity increases the boards' ability to acquire critical resources for the organization (Pfeffer, 1972, 1973; Pfeffer \& Salancik, 1978). Diverse boards can also provide a wider range of alternatives and criteria for choice (Eisenhardt \& Bourgeois, 1988). Previous research suggests board diversity increases the resource pool for the board and enhances overall board capability (Hillman \& Dalziel, 2003). The broader the base of the board's skill set, the wider the set of ideas and external sources the board can provide. Board diversity, then, should have the potential to increase innovation.

Though diversity stimulates creativity and innovation it also reduces cohesion and communication (Glick, Miller and Huber, 1993). Board members with diverse functional backgrounds can bring different approaches to problem solving. This may increase the alternatives available to solve complex problems, but at the same time, also increase the difficulty in achieving cohesive decision making (Michel \& Hambrick, 1992; Waller, Huber \& Glick, 1995). Social categorization theory suggests that when an individual is specialized in a particular area, he/she will attribute positive characteristics to his/her own group and negative attributes to other groups (Williams and O'Reilly, 1998). Functional background, which is a very observable and stable characteristic, is a demographic characteristic that individuals use for categorization, leading to in-group/out-group categorizations (Webber $\&$ Donahue, 2001). This social categorization process can lead to stereotyping and restricted communication. As a result, as board functional heterogeneity increases, board information sharing could decrease. This social categorization process could also prompt political behavior and conflict, thereby reducing cohesion. A potential outcome would be a decrease in the group's decision making ability (Knight, Pearce, Smith, Olian, Sims, Smith, and Flood, 1999; Hambrick, Cho, and Chen, 1996).

These negative effects can be pronounced in board settings because board member roles are part-time commitments, so board members have few opportunities to work together and smooth over differences. Empirical studies have found that 
heterogeneous boards are less likely to initiate strategic change (Goodstein et al., 1994). Forbes and Milliken (1999) proposed that job related diversity on the board increases the amount of cognitive conflict while decreasing the board's cohesiveness. Westphal and Bednar (2005) describe the construct of "pluralistic ignorance," where individual board members fail to share what might be commonly held insights due to a lack of common experiences with members of a diverse board. Although functional diverse board members possess greater knowledge resources, they may not be able to transform their diverse functional knowledge into effective board discussion and decision-making. The negative impact of board functional heterogeneity on team process makes board members less effective in performing their resource roles, which will negatively affect firm R\&D search.

Given the negative effects of functional diversity on board process effectiveness, we argue:

Hypothesis 1 a. As the functional diversity of the board increases, $R \& D$ intensity will decrease.

Functional heterogeneity will also have a specific effect on the board control function. Organizational control theory describes two control strategies for executive level work. Behavior-based control evaluates managerial performance based on the quality of the decision-making process, while outcome-based control evaluates managerial performance based on the measurable outcomes of the decision-making process (Eisenhardt, 1985). Diverse board members may find it difficult to concur on the best form of behavior based controls due to their varied experience bases. Difficulties in communication will restrict their ability to define the information and gain the knowledge necessary to use behavior-based controls. When information constraints become severe, directors rely more exclusively on financially based, that is, outcome-based, measures (Schaffer, 2002). Thus, a diverse board will be more likely to use outcome-based control.

Outcome-based control will increase the attention of managerial effort towards maximizing short-run profits and direct that effort away from the high risk-return strategies shareholders prefer (Cardinal, 2001; Hambrick and Snow, 1988). Outcome-based incentives are usually based on profits and stock prices. Since the link between $R \& D$ and profits is uncertain, managers under these outcome-based control systems will want to avoid the risk in R\&D investments. As importantly, outcome-based incentives are usually based on outcomes measured in the short-term. Innovation is an inherently long-term investment, and measures based on short-term outcomes may cause managers to be too responsive to the pressures for short-term 
profits, at the expense of important long-term investments (Porter, 1992). Functionally heterogeneous boards tend to use more outcome-based control, which will lead to less risk-taking in innovation.

Hypothesis $1 \mathrm{~b}$. As the functional diversity of board increases, use of behavior-based control will decrease.

\section{Board Composition and Firm Innovation}

Board composition denotes the mix of inside and outside directors. Outside directors are members of the board who lack current or past professional or personal associations with the firm (Cochran, Wood, \& Jones, 1985). While previous research has examined the impact of board composition on firm outcomes, the interactions between different board design characteristics has not been well explored. Here we argue different aspects of board design might complement or reinforce each other. While board members bring different resources and skills to the task of governance, these necessary skills may not be sufficient to accomplish the tasks required. Where board diversity captures capabilities and skills, board composition determines the tendencies of the board toward the choice of types of control (Hillman \& Dalziel, 2003). So board composition interacts with board diversity to determine firm innovation. We propose the influence of board composition on innovation is indirect because an incentive preference cannot lead to better performance unless matched with adequate knowledge and skills.

Outsiders are more independent in the control and monitoring of management, in that they do not face conflicts induced by evaluating themselves or their work colleagues, as inside directors do. However, outsiders may possess less tacit knowledge about the firm and may be less willing to provide resources than inside directors (Hillman \& Dalziel, 2003). So here we argue the effect of board composition on board resource provision role and monitoring role differ.

Because organizational innovation is a collective learning process, much of the new knowledge generated by research is firm-specific and tacit (Penrose, 1995; Teece, Pisano \& Shuen, 1997; O'Sullivan, 2000). Among board members, the tacit knowledge of a firm's innovation is retained by executive directors because they are the ones that directly shape the process of innovation. Outside directors may not fully comprehend the content and significance of the innovation. Some researchers propose that inside directors can better govern innovation (Lazonick \& O'Sullivan, 1996; Tylecote \& Conesa, 1999). 
Moreover, outsiders may feel less obligated to provide resources than inside directors. Westphal (1999) found that social ties between directors and CEOs can increase their frequency of advice and counsel. We believe insiders have more social ties with their CEOs than outsiders, and we expect that Westphal's findings about advice and counsel will extend to the provision of resources. Because outside directors know less about firm innovation and they are not tied to the firm and management, they may have less incentive to contribute their resources to the firm. When diverse board members are dominated by outsiders, their lowered level of interest in the resource role (compared to insiders) will further reduce the effectiveness of a diverse board.

Hypothesis 2a. The outsider ratio on the board will negatively moderate the relationship between board diversity and $R \& D$ intensity.

Agency cost arguments support a contrasting hypothesis in suggesting that more outsiders strengthen the monitoring and control function since outsiders are better aligned with shareholder interests (Cochran et al., 1985; Coughlan \& Schmidt, 1985; Kesner \& Johnson, 1990; Weisbach, 1988) and are less likely to be dominated by the firm's executives (Conyon \& Peck, 1998). Outsiders may help management avoid falling into a "competency trap" (Ranft \& O'Neill, 2001). Myopia in learning implies that organizations tend to engage in activities that they are more competent and familiar with, while overlooking the distant new opportunities (Levinthal $\&$ March, 1993). Executives, including inside directors, who are engaged in the management of the organization on a day-to-day basis, are more prone to fall into this trap (Levinthal \& March, 1993). Management may put R\&D spending into the projects that they familiar with or escalate past commitments (Staw, 1981), which reduces overall risk-taking. Outside directors, on the other hand, bring independent thinking and strategic advice to discourage management myopia. And when agency conflicts are suspected, outside directors are apt to become more vigilant to ensure owners' interest (Kroll, Wright, Toombs \& Leavell, 1997). Several researchers have shown that the proportion of outsiders on the board is positively associated with director's strategic involvement (Johnson et al., 1993; Judge \& Zeithaml, 1992). Thus, from this line of reasoning, firms with high outsider ratios on the board will have better control and monitoring, which can to a certain degree overcome the negative effect of board diversity. Outside directors will increase the vigilance of functionally diverse boards, reducing the negative effect of functional diversity, leading to more behavior-based control. 
Hypothesis $2 b$. The outsider ratio on the board will positively moderate the relationship between board diversity and the use of behavior-based controls.

Our overall model is depicted in Figure 1. We also summarize our key constructs in table 1 .

Figure 1

Integrated Model of Board Attributes, Board Roles and Innovation.

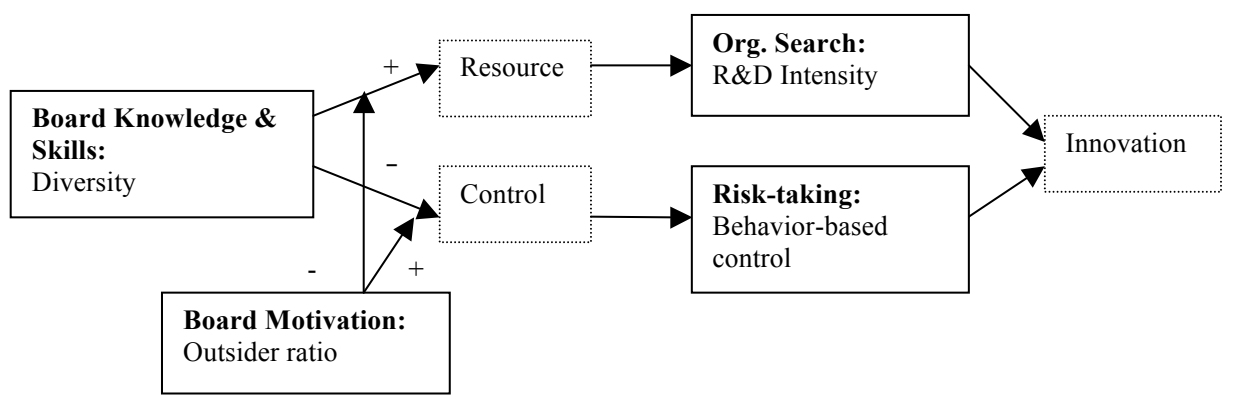

Table 1

Summary of Constructs and Measures

\begin{tabular}{|l|l|l|}
\hline \multicolumn{1}{|c|}{ Constructs } & \multicolumn{1}{c|}{ Definition } & \multicolumn{1}{c|}{ Measures } \\
\hline Board capital/capability & $\begin{array}{l}\text { The knowledge and skills } \\
\text { processed by the board } \\
\text { members to provide re- } \\
\text { sources and monitor }\end{array}$ & $\begin{array}{l}\text { Board functional back- } \\
\text { ground heterogeneity }\end{array}$ \\
\hline Board motivation/incentives & $\begin{array}{l}\text { The degree of effort board } \\
\text { members put into providing } \\
\text { resources and monitor. }\end{array}$ & $\begin{array}{l}\text { Board composition (ratio of } \\
\text { outside directors) }\end{array}$ \\
\hline Innovation search & $\begin{array}{l}\text { The amount of resources } \\
\text { committed to innovation. }\end{array}$ & R\&D intensity \\
\hline Innovation risk-taking & $\begin{array}{l}\text { The commitment of } \\
\text { resources to innovation } \\
\text { activities with a likelihood } \\
\text { of loss. }\end{array}$ & $\begin{array}{l}\text { CEO behavior-based } \\
\text { control }\end{array}$ \\
\hline
\end{tabular}




\section{METHODS}

\section{Sample and Data}

Hypotheses were tested using a sample of firms in research intensive industries. We selected research-intensive industries because innovations are of high importance in these industries. We expect the relationship between the board of directors and innovations will be more salient in these environments. Previous work (Hill and Snell, 1988) was used to identify seven research intensive industries: chemical manufacturing (NAICS code first three digit 325 except for 3254), pharmaceutical and medicine manufacturing (3254), machinery manufacturing (333), computer and electronic product manufacturing (334), electrical equipment, appliance and component manufacturing (335), computer programming \& data processing (514), and software publishers (511210). 20 firms were randomly selected in each industry. Due to missing data, the final sample contains 108 firms. A panel dataset of the sampled firms was collected from 1998 to 2001.

\section{Variables}

\section{Dependent Variables}

$R \& D$ intensity is measured as the relative $R \& D$ spending per employee of the firm. R\&D per employee is chosen because it is regarded as the best proxy for innovation and it is more stable than the other measures such as R\&D spending per sales or number of patents granted (Baysinger et al. 1991; Hill \& Snell, 1988). R\&D spending and number of employees are measured in million dollars and thousands respectively.

Behavior-based control is measured by the percentage of CEO compensation that is not tied to firm performance in the total compensation of CEO. CEO's compensation primarily consists of two elements: the fixed salary that is not tied to performance, and a variable part that is depended on the firm performance, such as bonus and stock options. So here we use CEO salary divided by CEO total compensation to calculate behavioral control. Total compensation is the sum of CEO salary, bonus, long-term incentives, other compensations, restricted stock awards, and value realized from stock options. These data elements are collected from Standard and Poor's COMPUSTAT executive compensation database, and supplemented by company proxy statement. All dependent variables are lagged by one year. 
Independent Variables

Board Diversity: Information on the directors serving in the sample firms was collected from the company proxy statement and company annual reports. Diversity is measured by the dissimilarity in the functional backgrounds of members on the board. Past researchers have studied the implication of group heterogeneity along a variety of dimensions, such as age, tenure and educational or occupational background. However, job related diversity is a better proxy of underlying cognitive diversity and more related to group strategy orientation (Golden \& Zajac, 2001; Wiersema \& Bantel, 1992). We developed six functional background groups (General Management, Marketing, R\&D, Finance and accounting, Law, and Operations), and calculated a Gibbs-Martin Index:

$1-\sum_{i=1}^{n} P_{i}^{2}$, where $P_{i}$ represents the proportion of a board accounted for by the $i^{\text {th }}$ group and $\mathrm{n}$ is the number of groups.

Board Outsider Ratio: Outsiders are identified as those directors who are not on the top management team and do not have a past relationship with the firm. Insiders are identified as those directors who are also top management team members. The outsider/total board member ratio is calculated by dividing the number of outsiders by number of total board members.

\section{Control Variables}

We utilized five control variables for R\&D intensity: Unrelated Diversification, Firm Size, Firm Past Performance, Board Tenure, and prior R\&D intensity. And we utilized three control variables for behavior-based control: Firm size, Firm Past Performance and Director Stock Ownership.

Diversification: Diversification, especially unrelated diversification, is usually associated with outcome-based controls on division managers. Under such controls, division managers will under invest in R\&D to maximize short-term performance (Baysinger \& Hoskisson, 1989). Empirical studies have found that diversification is negatively related to R\&D expenditure (Baysinger \& Hoskisson, 1989; Hill \& Snell, 1988).

We measure unrelated diversification with an entropy measure (Palepu, 1985). The entropy measure for a firm operating in $n$ industry segments is defined as:

$\sum_{i=1}^{n} P_{i} \ln \left(1 / P_{i}\right)$, where $\mathrm{P}_{\mathrm{i}}$ is the dollar value of sales attributed to business segment $i$ and $\ln (1 / \mathrm{Pi})$ is the natural logarithm of the inverse of its sales. Unrelated diversification is calculated based on the industry segments operating in different two-digit NAICS codes. 
Firm Size: Firm size is measured by the logarithm of firm revenue. Several empirical studies have found larger firms tend to spend more on R\&D (Bayinger \& Hoskisson, 1989; Baysinger et al., 1991). And firm size may influence CEO compensation structure because large firms have higher level pay. This data is gathered from Standard and Poor's COMPUSTAT industry annual database.

Past Performance: There are two possible performance impacts on $\mathrm{R} \& \mathrm{D}$ spending. First, profitability may give the firm more disposable resources and more confidence in investing in R\&D projects. Second, poor performance may spur the organization to increase R\&D in a search for new opportunities. Performance also influences CEO compensation because a portion of the CEO's pay is tied to firm performance. Therefore, we also use performance as the control variable for behavior-based control. We measure performance by firm return on assets. This data is calculated from the COMPUSTAT database.

Board Tenure: Tenure is the length of time the director has served on the board. Longer tenured boards may have more time to work together, thus affecting their process effectiveness. Board tenure is the average tenure of all the board of directors.

Prior $R \& D$ Intensity: Firm prior $\mathrm{R} \& \mathrm{D}$ intensity is controlled when testing the impact of boards on $R \& D$ intensity. Because $R \& D$ investment is often path-dependent, firms may follow previous routines on R\&D investment decisions. To control for this routinized part of R\&D investment, and identify the unique impact of boards on $R \& D$ decisions, we use prior R\&D intensity as a control variable. We also control for any potential environmental turbulence by using a dummy code for each year.

\section{Analysis}

We employed panel data regression techniques to test the hypotheses. We used the Hausman specification test to compare the fixed-effects and random-effects estimators and found that the fixed-effects model was appropriate. Fixed effects coefficients are analogous to standard regression coefficients.

\section{$\overline{\text { RESULTS }}$}

The means, standard deviations, and correlations among key variables are reported in Table 1 . 
Table 2

Means, Standard Deviations, and Correlations ${ }^{\mathrm{a}, \mathrm{b}}$

\begin{tabular}{|l|l|c|c|c|c|c|c|c|c|c|}
\hline & & Mean & S. D. & $\mathbf{1}$ & $\mathbf{2}$ & $\mathbf{3}$ & $\mathbf{4}$ & $\mathbf{5}$ & $\mathbf{6}$ & $\mathbf{7}$ \\
\hline 1 & $\begin{array}{l}\text { R\&D } \\
\text { intensity }\end{array}$ & 46.61 & 86.29 & & & & & & & \\
\hline 2 & $\begin{array}{l}\text { Behav- } \\
\text { ior-based } \\
\text { Control }\end{array}$ & 0.64 & 0.28 & $0.19^{*}$ & & & & & & \\
\hline 3 & $\begin{array}{l}\text { Board } \\
\text { diversity }\end{array}$ & 0.45 & 0.21 & $0.26^{*}$ & $0.16^{*}$ & & & & & \\
\hline 4 & $\begin{array}{l}\text { Board } \\
\text { outsider } \\
\text { ratio }\end{array}$ & 0.73 & 0.14 & 0.01 & $-0.24^{*}$ & $-0.17^{*}$ & & & & \\
\hline 5 & $\begin{array}{l}\text { Diversifi- } \\
\text { cation }\end{array}$ & 0.09 & 0.20 & $-0.16^{*}$ & $-0.12^{*}$ & -0.02 & $0.11^{*}$ & & & \\
\hline 6 & $\begin{array}{l}\text { Board } \\
\text { Tenure }\end{array}$ & 8.08 & 4.16 & $-0.22^{*}$ & $-0.10^{*}$ & -0.09 & $-0.19^{*}$ & 0.03 & & \\
\hline 7 & Firm Size & 5.33 & 2.67 & $-0.45^{*}$ & $-0.60^{*}$ & $-0.36^{*}$ & $0.30^{*}$ & $0.23^{*}$ & $0.21^{*}$ & \\
\hline 8 & $\begin{array}{l}\text { Firm Per- } \\
\text { formance }\end{array}$ & -0.05 & 0.39 & $-0.33^{*}$ & $-0.24^{*}$ & $-0.12^{*}$ & 0.05 & 0.07 & $0.24^{*}$ & $0.34^{*}$ \\
\hline
\end{tabular}

a There are 432 observations except for behavior-based control, which has 430 observations, and firm size, which has 426 observations.

$\mathrm{b} *<.05$

In our sample, firms spent an average of US\$46.61 million per thousand employees on R\&D. However, the standard deviation of US $\$ 86.29$ million shows firms vary greatly on R\&D spending. Sampled firms also slightly favor behavior-based control, as suggested by the fact that, on average, $64 \%$ of CEO compensation is fixed and not tied to firm performance. The standard deviation of $28 \%$ suggests that not all firms use behavior-based control as a major control strategy. On further examination of the correlations, we found R\&D intensity and behavior-based control were not very correlated with each other (0.17).

We will present the results of the direct effects for board diversity and board composition on research intensity and on the use of behavioral controls. We will then follow with a discussion of the interaction effects for board functional diversity and board composition. 
Table 3

Results of Linear Regression Analysis on R\&D Intensitye

\begin{tabular}{|c|c|c|c|c|}
\hline Variable & Model 1 & Model 2 & Model 3 & Model 4 \\
\hline Year dummies & Included & Included & Included & Included \\
\hline Constant & -46.81 & -18.32 & -11.72 & -12.23 \\
\hline Firm Size & $19.26^{\star \star \star}$ & $20.14^{\star \star \star}$ & $20.21^{* \star *}$ & $20.24^{\star \star *}$ \\
\hline $\begin{array}{l}\text { Prior Perfor- } \\
\text { mance }\end{array}$ & $-33.36^{\star \star}$ & $-37.94^{\star \star}$ & $-37.99^{\star \star}$ & $-37.80^{\star \star}$ \\
\hline Diversification & 3.25 & 1.89 & .85 & .80 \\
\hline Board Tenure & -.49 & -1.00 & $-1.05^{\star \star \star}$ & $-1.03^{\star \star \star}$ \\
\hline $\begin{array}{l}\text { Prior R\&D } \\
\text { Intensity }\end{array}$ & $-.27^{\star \star \star}$ & $-.29^{\star \star \star}$ & $-.29^{\star \star \star}$ & $-.29^{\star \star \star}$ \\
\hline Board diversity & & $-63.17^{\star}$ & $-63.65^{\star}$ & $-62.88^{\star}$ \\
\hline Outsider ratio & & & -8.58 & -9.10 \\
\hline $\begin{array}{l}\text { Board diversity } \\
\times \text { Outsider ratio }\end{array}$ & & & & -31.39 \\
\hline $\mathrm{R} 2$ & $.17^{\star \star \star}$ & $.20^{\star \star \star}$ & $.20^{* *}$ & $.20^{\star *}$ \\
\hline R2 Change & & $.03^{*}$ & .00 & .00 \\
\hline
\end{tabular}

${ }^{*}<.05,{ }^{* *}<.01,{ }^{* \star *}<.001$

Table 3 presents details of the regression on R\&D intensity. Stepwise regression analysis was used to assess the effects of the independent variable and their interaction.

Model 1 examined the effects of control variables on R\&D intensity. These variables explained about $17 \%$ of the total variance of $R \& D$ intensity of sample firms. Specifically, prior firm performance and prior R\&D intensity was negatively associated with current $R \& D$ intensity ( $<<.05, p<.01$ respectively) and firm size was positively related to $R \& D$ intensity $(p<.05)$. The overall model significantly explains the variance in $R \& D$ intensity $(p<.01)$.

In model 2, the variable, board diversity, was added. As can be seen in the change in R-square statistics at the bottom of table 2, board diversity added an additional $(3 \%)$ and significant $(\mathrm{p}<.05)$ amount to the variance explained by the control variables. The effect of board diversity on $\mathrm{R} \& \mathrm{D}$ was negative and significant $(p<.05)$. Even when board outsider ratio is added (model 3 ), this effect remains sig- 
nificant. This finding is consistent with hypothesis 1a. Board diversity is negatively related to R\&D intensity. The conflict induced by the diverse backgrounds apparently overwhelms the variety in knowledge and/or connections potentially provided by diversity.

Table 4

Results of Fixed Effect Regression on Behavior-based Control

\begin{tabular}{|c|c|c|c|c|}
\hline Variable & Model 1 & Model 2 & Model 3 & Model 4 \\
\hline Year dummies & Included & Included & Included & Included \\
\hline Constant & $.49^{\star \star}$ & $.57^{\star \star}$ & .40 & $1.04^{*}$ \\
\hline Firm Size & $.04^{\star}$ & $.04^{\star}$ & $.04^{\star}$ & .04 \\
\hline $\begin{array}{l}\text { Firm Perfor- } \\
\text { mance }\end{array}$ & -.025 & -.04 & -.03 & -.04 \\
\hline Board Tenure & -.21 & -.01 & -.01 & -.01 \\
\hline Diversification & -.06 & -.07 & -.04 & -.04 \\
\hline Board diversity & & -.17 & -.16 & $-1.55^{\star}$ \\
\hline Outsider ratio & & & .21 & -.59 \\
\hline $\begin{array}{l}\text { Board diversity } \\
\times \text { Outsider ratio }\end{array}$ & & & & $1.83^{*}$ \\
\hline R2 & $.08^{*}$ & $.08^{*}$ & $.09^{*}$ & $.11^{\star *}$ \\
\hline R2 Change & & .00 & .01 & $.02^{\star \star}$ \\
\hline
\end{tabular}

${ }^{\star}<.05,{ }^{* \star}<.01,{ }^{* \star *}<.001$

The results of tests for behavior-based control are shown in Table 4. Similar to the analysis for R\&D intensity, stepwise regression was used to test the effects of the variables we are interested in.

In model 1, control variables were entered, and this model explains about $8 \%$ of total variance of behavior-based control $(\mathrm{p}<.05)$. Specifically, firm size was positively related to behavior-based control $(\mathrm{p}<.05)$. After adding board diversity in model 2, the model R-square increased insignificantly, as board diversity was not significant. In model 4 , when the measure of composition and the interaction of diversity and composition were added, the model increased R-square by $.02(p<.01)$. In this model, board diversity was negatively related to behavior-based control $(\mathrm{p}<.05)$. So hypothesis $1 \mathrm{~b}$ received support. 
With respect to interaction affects, as seen on Table 3, the interaction effect of board diversity and board outsider ratio did not improve the total variance explained for R\&D intensity. The coefficient of the interaction effect was negative as predicated, but not significant. Thus hypothesis $2 \mathrm{a}$ was not supported.

In contrast, as presented in Table 4, the interaction between board diversity and board outsider ratio had a positive and significant $(\mathrm{p}<.01)$ effect on the use of behavior based controls. This finding supports hypothesis $2 \mathrm{~b}$, which predicted that composition would moderate the negative relationship between board diversity and the use of behavioral controls. We use a graph to visually present the interaction effect in figure 2 .

\section{Figure 2}

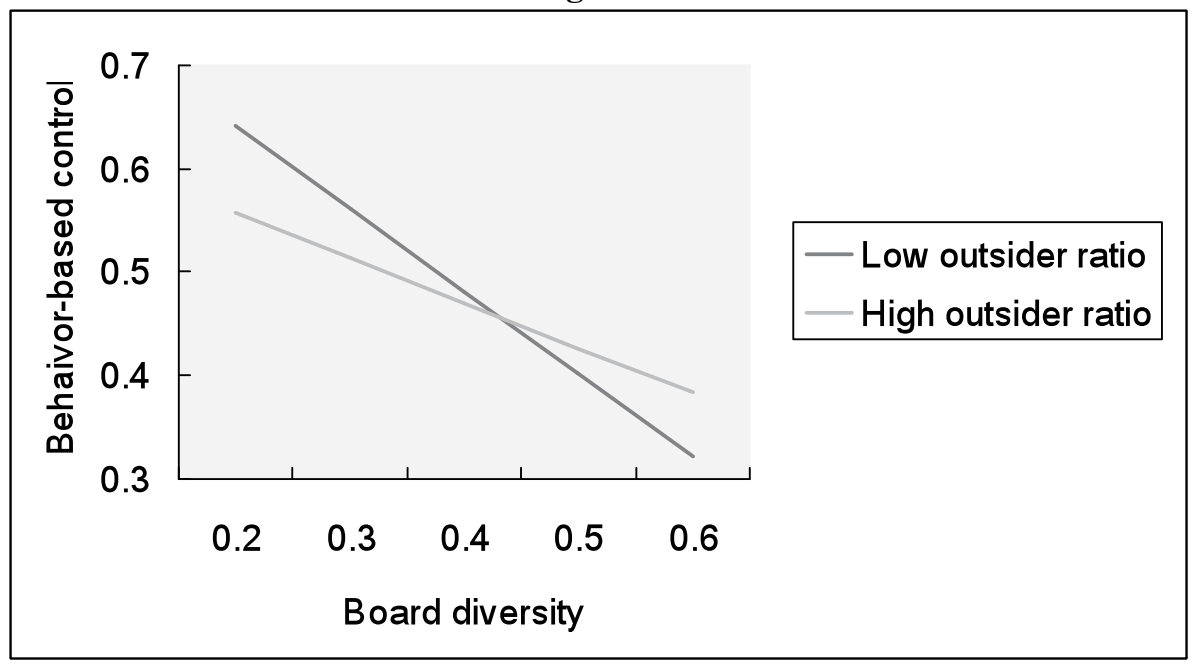

Specifically, we used standardized regression coefficients from the final regression equation to plot the relation between board diversity and behavior-based control at low (one standard deviation below the mean) and high (one standard deviation above the mean) levels of board outsider ratio. As shown in Figure 2 and as expected, board diversity is negatively related to behavior-based control when the outsider ratio is low. Yet, when outsider ratio is high, the negative relationship between board diversity and behavior-based control became less steep, indicating the negative relationship became weaker for high outsider ratio boards. 


\section{DISCUSSION AND CONCLUSIONS}

In this study, we model the relationship between the board characteristics and $R \& D$ intensity. We expected that resources and the form of controls affect $R \& D$ intensity. Board diversity and board composition jointly affect board resource and control roles.

Board diversity represents board knowledge and skills. We found functional diversity will negatively impact board resource and control roles, leading to lower R\&D intensity and less behavior-based control. Functional diverse boards face more communication challenges and this may reduce board effectiveness. Several other studies also found that functional background diversity, compared to other types of diversity, may not create positive board dynamics as expected. Westphal and Bednar (2005) found board functional background diversity tended to exacerbate pluralistic ignorance at a greater extent than industry background diversity. Tuggle et. al. (2010) examined board functional and industry diversity and found board functional diversity did not increase their discussion of entrepreneurial issues. These studies, combined with our findings, suggest board members should not be too diverse in their functional background, for those firms which depend on research and development. Alternately, patterns of diversity may be more important than the absolute levels of diversity. We would expect that issues such as agenda setting and work climate affect whether diversity has a positive or negative impact, and these deserve direct attention.

Our research also suggests board composition, as indicated by the ratio of outside directors, will have an indirect impact on firm innovation. The board outsider/insider dichotomy mainly reflects the board's dependence on its management, which determines director motivation to provide resources and exert control. Because board independence may help the board meet its control more effectively, but reduce board willingness to provide resources, the moderating effect of board composition on the relationship between board diversity and R\&D intensity introduces complexity in predicting the expected impact on R\&D. Our findings show a positive interaction effect of board composition and board diversity on behavior-based control. More diverse boards lead to a reduction in the use of behavior controls, but this reduction is less drastic in boards with a higher proportion of outsiders. Therefore, hiring outside directors can improve the control effectiveness of functional diverse boards. Although we also found a negative interaction between board composition and board diversity on R\&D intensity, the effect is not statistically significant. This non-finding may reflect the fact that the effect of functional diversity on R\&D in- 
tensity is very strong, so changes in outsider ratio will not generate much variance to that relationship. A larger sample in future research might provide more insight into the exact nature of this effect. The multi-faceted effects of board composition on board roles suggest putting more outside directors on boards can create a double edged sword, in that potentially positive and negative outcomes accrue. The multi-faceted effects may help explain why studies fail to find consistent effects of the board outsider ratio on firm performance. Most importantly, the dominant reliance of past studies on archival data may indicate that researchers have over-emphasized structural aspects of board design (functional diversity and board composition) without recognizing how the constructs interact to influence forms of control.

Although there have been many studies on board of directors and varied aspects of firm innovation, knowledge on the relationship between boards and innovation remains limited. We believe the key to a better understanding of this relationship is to recognize the complex nature of the board's roles and the complex nature of innovation. First, our research suggests that boards serve different roles. Consistent with resource dependency theory, boards provide resources. Consistent with agency theory, boards monitor management. By combining two theoretical perspectives, we provide a clearer view of the relationship between board characteristics (diversity and composition) and the resource provision and control roles. Board knowledge and skills and effective design of controls by the board each contribute to innovation.

Our study also suggests that innovation taps two board roles. Due to overreliance on a single dimension, previous research yielded inconsistent findings between board characteristics and firm innovation. We consider two board roles: providing resources and designing rewards. Board composition has moderating effects on the board's resource role and board's control role. We found a higher outsider ratio may help boards to better perform its control role, but not its resource providing role. These distinctions should lead to future study on the varied roles of boards and their different contribution to the innovation process.

The limitations of this study should also be noted. First, our measures of diversity and composition are only proxies for the underlying behavior. Future studies could find more direct measures to capture board behavior. Secondly, we use board functional background as an indicator of board knowledge and experiences. This may not be the only or best indicator. Measures that go beyond demographic backgrounds may better capture board dynamics. In addition, new forms of communication technology may be changing the nature of board dynamics. Finally, our data do not include the passage of Sarbanes-Oxley. How did this exogenous policy change 
the relationship between boards and firm innovation? The changed rules for board governance provide several interesting topics for future studies.

Innovation is long-term and difficult, yet critical to firm survival. Our study suggests that boards of directors are an important component in providing both the means (via resources) and the will (via controls) to sustain innovation. The cure for myopia, then, has to involve the board.

\section{REFERENCES}

Amihud, Y. and Lev, B. (1981). Risk reduction as a managerial motive for conglomerate mergers. Bell Journal of Economics, 12, 99-110.

Baysinger, B. \& Hoskisson, R.E. (1989). The composition of boards of directors and strategic control: Effects on corporate strategy. Academy of Management Review, 15, 72-87.

Baysinger, B.D., Kosnik, R.D. \& Turk, T. A. (1991). Effects of board and ownership structure on corporate R\&D strategy. Academy of Management Journal, 34, 205-214.

Burgelman, R. A. \& Sayles, L.R. (1986). Inside corporate innovation: Strategy, structure, and managerial skills. New York: Free Press.

Cardinal, L.B. and D.E. Hatfield (2000). Internal knowledge generation: The research laboratory and innovative productivity in the pharmaceutical industry. Journal of Engineering and Technology Management, 17, 247-271.

Cardinal, L.B. (2001). Technology innovation in the pharmaceutical industry. Organization Science, 12(1), 19-36.

Christensen, C.M. (1997). The innovator's dilemma: When new technologies cause great firms to fail. Boston, MA: Harvard Business Press.

Cochran, P., Wood, R. \& Jones, T. (1985). The composition of boards of directors and incidence of golden parachutes. Academy of Management Journal, 28, 664671.

Cohen, W.M. \& Levinthal, D.A. (1990). Absorptive capacity: A new perspective on learning and innovation. Administrative Science Quarterly, Special issue on technology, organizations, and innovation, 35, 128-152.

Cooper, A. \& Schendel, D. (1976). Strategic responses to technological threats. Business Horizons, 19(1), 267-280.

Copeland, T., \& Weston, J.F. (1979). Financial theory and corporate policy. Reading, MA: Addison-Wesley. 
Conyon, M. J. \& Peck, S.I. (1998). Board control, remuneration committees, and top management compensation. Academy of Management Journal, 41(2), 146-158. Coughlan A.T., Schmidt, R.M. (1985). Executive compensation, management turnover and firm performance: An empirical investigation. Journal of Accounting and Economics, 7, 43-66.

Cyert, R.M., \& March, J.G. (1963). A behavioral theory of the firm. Englewoof Cliffs, NJ: Prentice-Hall.

Drucker, P.F. (1995). The information executives truly need. Harvard Business Review, Jan.-Feb, 54-62.

Eisenhardt, K.M. (1985). Control: Organizational and economic approaches. Management Science, 31(2), 134-150.

Eisenhardt, K. \& Bourgeois, L. (1988). Politics of strategic decision making in high-velocity environments: Toward a midrange theory. Academy of Management Journal, 31, 737-770.

Forbes, D.P. \& Milliken, F.J. (1999). Cognition and corporate governance: Understanding boards of directors as strategic decision-making groups. Academy of Management Review, 24, 485-505.

Glick, W. H., Miller, C.C., \& Huber, G.P. (1993). The Impact of upper-echelon diversity on organizational performance. In Organizational change and redesign, Glicks W. H., G. Huber P. (eds). New York: Oxford University Press.

Golden, B.R. \& Zajac, E.J. (2001). When will boards influence strategy? Inclination $\times$ power $=$ strategic change. Strategic Management Journal, 22, 1087-1111.

Gomez-Mejia, L.R., Haynes, K.T., Nunez-Nickerl, M., Jacobson, K.J.L, \& Moyano Fuentes, J. (2007). Socioemotional wealth and business risks in family-controlled firms: Evidence from Spanish Olive Mills. Administrative Science Quarterly. 52: 106-137.

Goodstein, J. \& Boeker, W. (1991). Turbulence at the top: A new perspective on governance structure changes and strategic change. Academy of Management Journal, 34(2), 306-330.

Goodstein, J., Gautam, K. \& Boeker, W. (1994). The effects of board size and diversity on strategic change. Strategic Management Journal, 15(3), 241-250.

Greve, H.R. (2003). A behavioral theory of R\&D expenditures and innovations: Evidence from shipbuilding. The Academy of Management Journal, 46(6), 685.

Hambrick, D.C. \& Mason, P.A. (1984). Upper echelons: The organization as a reflection of its top managers. Academy of Management Review, 9(2), 193-206. 
Hambrick, D.C. \& Snow, C.C. (1988). Strategic reward systems. In C.C. Snow (Ed.), Strategy, organization design, and human resource management. Greenwich, CT: JAI Press.

Hambrick D.C., Cho T., \& Chen M.(1996). The influence of top management team heterogeneity on firm's competitive moves. Administrative Science Quarterly, 41, 659-684.

Hill, C.W.L \& Snell. S.A. (1988). External control, corporate strategy, and firm performance in research-intensive industries. Strategic Management Journal, 9(6), 577-590.

Hillman, A.J. \& Dalziel, T. (2003). Board of directors and firm performance: Integrating agency and resource dependence perspectives. The Academy of Management Review, 28(3), 383.

Hillman, A.J., Withers, M.C., \& Collins, B.J. 2009. Resource dependence theory: A review. Journal of Management, 35(6): 404-427.

Hill, C.W. \& Snell, S.A. (1988). External control, corporate strategy, and firm performance in research-intensive industries. Strategic Management Journal, 9(6), 577-590.

Hoskisson, R.E., Hitt, M.A., Johnson, R.A. \& Grossman, W. (2003). Conflicting voices: The effects of institutional ownership heterogeneity and internal governance on corporate innovation strategies. The Academy of Management Journal, 45(4), 697.

Jensen, M.C. \& Meckling, W.H. (1976). Theory of the firm: Managerial behavior agency costs and capital structure. Journal of Financial Economics, Oct, 305360 .

Judge, W.Q. \& Zeithaml, C.P. (1992). Institutional and strategic choice perspectives on board involvement in the strategic decision process. Academy of Management Journal, 35(4), 766-794.

Johnson, R.A., Hoskisson, R.E. \& Hitt, M.A. (1993). Board of director involvement in restructuring: The effects of board versus managerial controls and characteristics. Strategic Management Journal, Summer special issue, 14, pp. 33-50.

Jones, C.D., Makri, M., \& Gomez-Mejia, L.R. (2008). Affiliate directors and perceived risk bearing in publicly traded, family-controlled firms: The case of diversification. Entrepreneurship: Theory and Practice, 32: 1007-1026.

Kesner I.F., \& Johnson, R.B. (1990). An investigation of the relationship between board composition and stockholder suits. Strategic Management Journal, 11(4), 327-337. 
Kor, Y.Y. \& Misangyi, V.F. (2008). Outside directors' industry-specific experience and firms' liability of newness. Strategic Management Journal, 29: 1345-1355.

Knight D., Pearce C.L., Smith K.G., Olian J.D., Sims H.P., Smith K.A., \& Flood P. (1999). Top management team diversity, group process, and strategic consensus. Strategic Management Journal, 20, 445-465.

Kosnik, R.D. (1990). Effect of board demography and directors' incentives on corporate greenmail decisions. Academy of Management Journal, 33, 129-150.

Kroll, M., Wright, P., Toombs, L. \& Leavell, H. (1997). Form of control: A critical determinant of acquisition performance and CEO rewards. Strategic Management Journal, 18(2), 85-96.

Kroll, M., Walters, B.A. \& Le, S. (2007). The impact of board composition and top management team ownership structure on post-IPO performance in young entrepreneurial firms. Academy of Management Journal, 5: 1198-1216.

Lane, P.J., Cannella, A.A. \& Lubatkin, M.H. (1998). Agency problems as antecedents to unrelated mergers and diversification: Amihud and Lev reconsidered. Strategic Management Journal, 19, 555-578.

Lazonick, W., \& O'Sullivan, M. (1996). Organization, finance, and international competition. Industrial and Corporate Change, 5(1), 1-49.

Levinthal D.A. \& March, J.G. (1993). The myopia of learning. Strategic Management Journal, 14, 95-112.

March, J.G., \& Shapira. Z. (1987). Managerial perspectives on risk taking. Management Science, 33: 1404-1418.

Michel J.G., \& Hambrick, D.C. (1992). Diversification posture and top management team characteristics. Academy of Management Journal, 35: 9-37.

Miller, D. (1990). The Icarus paradox: How exceptional companies bring about their downfall: New lessons in the dynamics of corporate success, decline and renewal. New York: Harper Business.

Oviatt, B.M. (1988). Agency and transaction cost perspectives on the managershareholder relationship: Incentives for congruent interests. Academy of Management Review, 13(2), 214-226.

O'Sullivan, M. (2000). The innovative enterprise and corporate governance. Cambridge Journal of Economics, 2000 (24), 393-416.

Palepu, K. (1985). Diversification strategy, profit performance and the entropy measure. Strategic Management Journal, 6, 239-255.

Pfeffer, J. (1972). Size and composition of corporate boards of directors: The organization and its environment. Administrative Science Quarterly, 17, pp. 218-229. 
Pfeffer, J. (1973). Size, composition, and function of hospital boards-of-directors: A study of organization-environment linkage. Administrative Science Quarterly, $18(3), 349$.

Peffer, J. \& Salancik, G.R. (1978). The external control of organizations: A resource dependence perspective. New York: Harper \& Row.

Porter, M.E. (1992). Capital disadvantage: America's failing capital investment systems. Harvard Business Review, Sept./Oct, 65-83.

Ranft A.L., \& O'Neill H.M. (2001). Board composition and high-flying founders: Hints of trouble to come? Academy of Management Executive, 15(1), 126-138.

Schaffer, B.S. (2002). Board assessment of managerial performance: An analysis of attribution processes. Journal of Managerial Psychology, 17(2), 95-115.

Staw, B.M. (1981). The escalation of commitment to a course of action. Academy of Management Review, 6, 577-587.

Teece, D., Pisano, G. \& Shuen, A. (1997). Dynamic capabilities and strategic management. Strategic Management Journal, 18(7), 524.

Tuggle C.S., Schnatterly K., \& Johnson R.A. (2010). Attention patterns in the boardroom: How board composition and processes affect discussion of entrepreneurial issues. Academy of Management Journal, 53(3), 550-571.

Tylecote, A., \& Conesa, E. (1999). Corporate governance, innovation systems and industrial performance. Industry and Innovation, 6(1): 25.

Waller, M.J., Huber, G.P. \& Glick, W.H. (1995). Functional background as a determinant of executives' selective perception. Academy of Management Journal, 38, 943-974.

Webber, S.S. \& Donahue, L.M. (2001). Impact of highly and less job-related diversity on work group cohesion and performance: A meta-analysis. Journal of Management, 27, 141-162.

Weisbach, M.S. (1988). Outside directors and CEO turnover. Journal of Financial Economics, 20, 431-460.

Westphal, J.D, \& Bednar, M.K. (2005). Pluralistic ignorance in corporate boards and firms' strategic persistence in response to low firm performance. Administrative Science Quarterly, 49, 262-298.

Walsh, J.P. \& Seward, J.K. (1990). On the efficiency of internal and external corporate control mechanisms. Academy of management review, 15(3), 421-458.

Westphal, J. (1999). Collaboration in the boardroom: Behavioral and performance consequences of CEO-board social ties. Academy of Management Journal, 42, $7-25$. 
Wiersema, M.F. \& K.A. Bantel (1992). Top management team demography and corporate strategic change. Academy of Management Journal, 35, 91-121.

Williams K.Y., \& O'Reilly C.A. 1998. Demography and diversity in organizations: A review of 40 years of research. In Research in Organizational Behavior, Staw B.M., Cummings L.L. (eds) (pp. 77-140). Greenwich, CT: JAI Press.

Zahra, S.A. \& Pearce, J.A. (1989). Boards of directors and corporate financial performance: A review and integrative model. Journal of Management, 15(2), 291334.

Zahra, S.A. (1996). Governance, ownership, and corporate entrepreneurship: The moderating impact of industry technological opportunities. Academy of Management Journal, 39(6), 1713-1735.

Zahra, S.A., Neubaum, D.O. \& Huse, M. (2000). Entrepreneurship in medium-size companies: Exploring the effects of ownership and governance systems. Journal of Management, 26(5), 947-976.

\section{BIOGRAPHICAL SKETCH OF AUTHORS}

Xuanli Xie is the assistant professor of strategic management at National School of Development, Peking University. She received her PhD in strategic management from the University of North Carolina at Chapel Hill. Her research interests include corporate governance, innovation, entrepreneurship, and international business.

Hugh O'Neill is Edward M. O'Herron, Jr. Distinguished Scholar and Professor of Strategy and Entrepreneurship at Kenan-Flalger Business School, the University of North Carolina at Chapel Hill. He received his PhD from the University of Massachusetts. His research interests include turnaround strategies, corporate governance, mergers, entrepreneurship in emerging and recovering economies and managerial decision making. 